\title{
Corticotropin-releasing hormone (Crh) maps to mouse Chromosome 3
}

\author{
Lauren T. Knapp, ${ }^{1}$ Catherine E. Keegan, ${ }^{1,2}$ Audrey F. Seasholtz, ${ }^{3}$ and Sally A. Camper ${ }^{1}$ \\ ${ }^{1}$ Department of Human Genetics, University of Michigan Medical School, Ann Arbor, Michigan 48109-0618, USA \\ ${ }^{2}$ Graduate Program in Cellular and Molecular Biology, University of Michigan Medical School, Ann Arbor, Michigan 48109-0618, USA \\ ${ }^{3}$ Department of Biological Chemistry and Mental Health Research Institute, University of Michigan Medical School, \\ Ann Arbor, Michigan 48109-0618, USA
}

Received: 26 May 1993 / Accepted: 10 June 1993

The mammalian stress response is mediated in large part via the hypothalamus-anterior pituitary-adrenal (HPA) axis. The key hypothalamic releasing factor in this axis is corticotropin-releasing hormone ( $\mathrm{CRH})$ (Vale et al. 1983). This 41-amino-acid peptide is released from the median eminence and transported via the hypophyseal portal blood system to the anterior pituitary, where it increases synthesis of pro-opiomelanocortin mRNA and secretion of adrenocorticotropin (ACTH; Vale et al. 1981). ACTH stimulates the production of glucocorticoids in the adrenal cortex. In addition to the role of CRH within the HPA stress axis, CRH is expressed in many other regions within the central nervous system where it is thought to influence behavioral, autonomic, and immunological responses to stress (Brown and Fisher 1985; Irwin et al. 1992; Koob and Bloom 1985).

CRH has been assigned to human Chromosome (Chr) 8 by Southern blot analysis of somatic cell hybrids and localized to band $8 \mathrm{q} 13$ by in situ hybridization of metaphase chromosomes (Arbiser et al. 1988). Synteny homology between mice and humans suggested that $\mathrm{Crh}$ would map to mouse $\mathrm{Chr} 3,4,8$, or 15 (Nadeau et al. 1992).

We mapped $C r h$ to mouse $C h r 3$ using a $M$. spretus interspecific backcross (C57BL/6J-tg9257 $\times$ SPRET/Ei) $\times$ C57BL/6J (Bain et al. 1993; Barrow et al. 1993). This cross was previously typed at four loci on distal Chr 3, Gba, Hsd3b, Tshb, and Amy-1 (Bain et al. 1993). We extended the characterization of this cross by typing two markers on proximal $\mathrm{Chr} 3$, carbonic anhydrase 2 (Car-2) and interleukin 2 ( $\mathrm{Il}-2)$. Southern blot hybridization was used to map $\mathrm{Crh}$ and Car-2, an enzyme that catalyzes the reversible hydration reaction of carbon dioxide to bicarbonate, (Fig. 1; Venta et al. 1985). $I l-2$, a lymphokine that induces activated T-cells to complete the cell cycle, was mapped

Correspondence to: S.A. Camper by PCR (Fig. 1; Dietrich et al. 1992; Fiorentino et al. 1989). Haplotype analysis of 53 animals and minimization of crossover frequency was used to deduce the gene order and genetic distance (cM): $\mathrm{Crh}, \mathrm{Car}-2-11.3$ $\pm 4.4-I l-2-22.6 \pm 5.7-G b a$. The map constructed from these data (Fig. 2) is consistent with the location presented for Car-2, Il-2, and Gba on the consensus map (Meisler and Seldin 1991), although these genes have not been previously localized relative to one another. Three carbonic anhydrase genes have been localized in close proximity on human $\mathrm{Chr} 8$ and mouse $\mathrm{Chr} 3$ (Beechey et al. 1990; Eicher et al. 1976; Nakai et al. 1987). Our observation that $\mathrm{Car}-2$ and $\mathrm{Cr} h$ cosegregate extends the synteny conservation between mouse $\mathrm{Chr}$ 3 and human Chr 8.

It is difficult to predict the phenotypes that might result from $\mathrm{Crh}$ mutations because of the multiple roles of CRH within the HPA axis and central nervous system. Human clinical studies suggest that hypothalamic CRH deficiency can result in adrenocortical insufficiency and hypopituitarism (Fehm et al. 1976). Animal studies suggest that other consequences of CRH deficiency are possible. For example, impaired synthesis and secretion of $\mathrm{CRH}$ in the paraventricular nucleus of the hypothalamus of the Lewis (LEW/N) rat leads to an increased susceptibility to streptococcal cell wall-induced arthritis (Sternberg et al. 1989). The expression of $\mathrm{CRH}$ in multiple regions of the mouse brain and in some peripheral tissues beginning at embryonic day 13.5 suggests that $\mathrm{CRH}$ expression may also play an important role in development (C. Keegan, unpublished data). Therefore, a deficiency of CRH could result in a variety of phenotypes, and a total loss of CRH function could potentially be lethal. Increased CRH activity often results in hypercortisolism. In humans, hypercortisolism is associated with Cushing's syndrome and is characterized by truncal obesity, muscle wasting, and decreased fertility (Nelson 1989). A similar phenotype was observed in transgenic mice that overexpress CRH (Stenzel-Poore et al. 
1992). High levels of ectopic CRH expression in transkaryotic rats caused marked adrenal cortical hyperplasia and anterior pituitary corticotrope hyperplasia and hypertrophy (Asa et al. 1992; Hammer et al. 1992). Finally, hypersecretion of CRH is thought to play a role in clinical depression and anorexia nervosa, suggesting that animals with increased $\mathrm{CRH}$ levels would exhibit altered motor activity, feeding, and sexual behavior (Gold and Chrousos 1985; Krahn et al. 1986, 1990; Levine et al. 1983; Nakahara 1983; Nemeroff et al. 1984; Sirinathsinghji et al. 1983; Sutton et al. 1982).

Two mutations are located on proximal mouse Chr 3 , cocoa (coa) and subtle gray (sut) (Meisler and Seldin 1991). The phenotypes of these two mutants do not correlate with those suggested for CRH deficiency from human and animals studies.
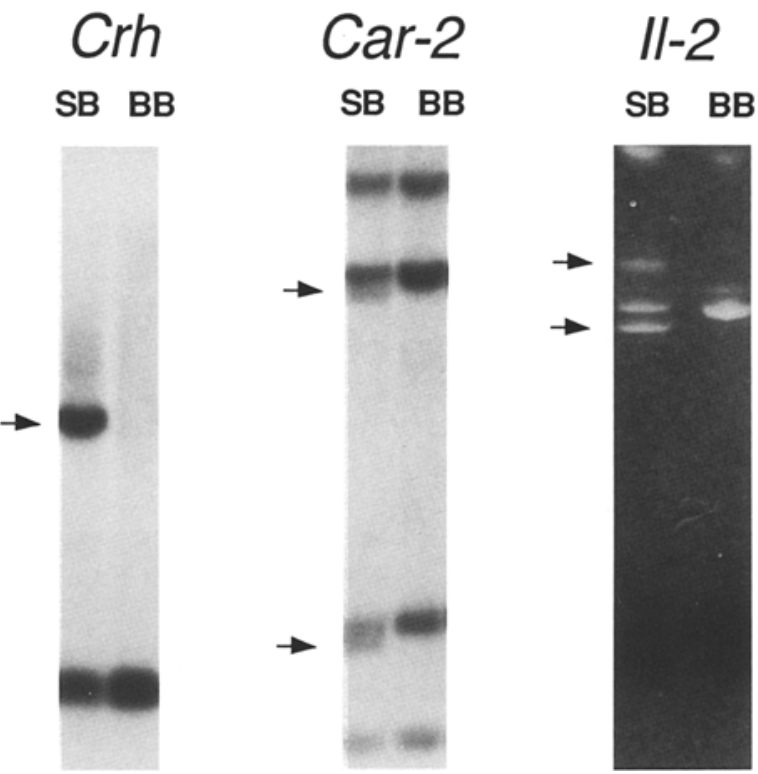

Fig. 1. Polymorphisms used to type backcross progeny on Chr 3 . Car-2 and Crh were typed with RFLPs detected by Southern blot analysis, and $\mathrm{Il}-2$ was typed with a simple sequence repeat polymorphism detected by PCR. Gba was previously localized by PCR (Bain et al. 1993). Southern blots were performed as previously described (Sambrook et al. 1989). All gels were transferred to Zeta-Probe nylon filters (Bio-Rad). Probes were labeled by the random hexanucleotide method (Feinberg and Vogelstein 1982). Hybridization was carried out at $65^{\circ} \mathrm{C}$. The mouse $C r h$ cDNA probe, pGem4ZPst578 (Seasholtz et al. 1991), revealed a polymorphism in genomic DNA digested with PstI. The SPRET/Ei and C57BL/6J alleles produced hybridizing fragments of 2.6 and $0.5 \mathrm{~kb}$, respectively. A mouse cDNA clone for Car-2, pBSMACII-Sph, provided by P. Venta, (Venta et al. 1985), detected an $S s p I$ polymorphism. The SPRET/Ei specific alleles revealed fragments of $4.2,3.1$, and $0.9 \mathrm{~kb}$, and the C57BL/6J specific alleles revealed $4.2,3.2,1.0$, and $0.7 \mathrm{~kb}$ fragments. Il-2 was mapped by PCR using $500 \mathrm{ng}$ of mouse genomic DNA as a template in a $25-\mu \mathrm{l}$ reaction volume with $10 \mu \mathrm{mol}$ of each primer and $2 \mu \mathrm{mol}$ each of dATP, dCTP, dGTP, and dTTP. Primers for Il-2 (D3Mit21) were extended with 1-2 U of Taq polymerase (Dietrich et al. 1992). The amplification products were fractionated through $8 \%$ polyacrylamide and visualized by ethidium bromide staining. The amplification products were 217 and 265 bp for SPRET/Ei DNA and 237 bp for C57BL/6J DNA. A subset of animals were typed at $I l-2$ by PCR with the same primers radiolabeled with $\gamma^{32}$ P-ATP and the amplification products visualized by autoradiography as previously described (Buckwalter et al. 1992). Arrowheads designate the $M$. spretus -specific alleles present in genomic DNA from (C57BL/6J-tg9257-SPRET/Ei $\times$ C57BL/6J) $\mathrm{F}_{1}$ mice (SB) but absent in C57BL/6J (BB) mice.

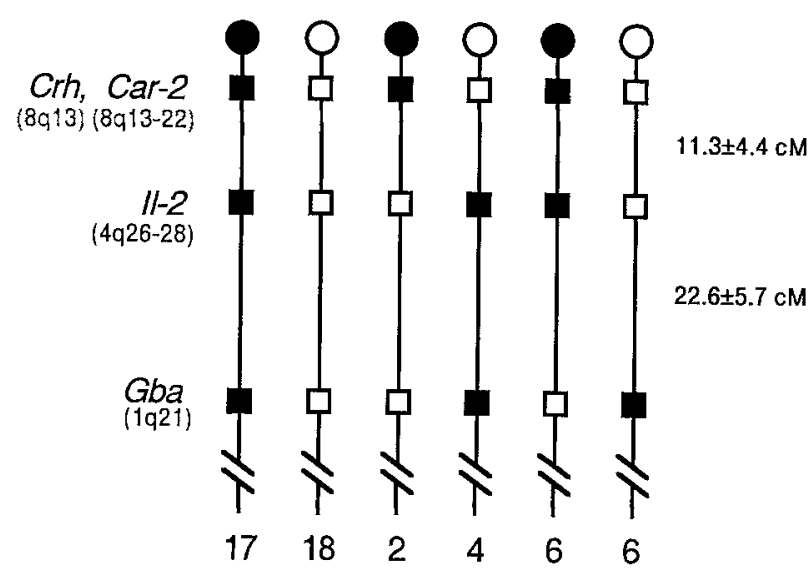

Fig. 2. The haplotype distribution of 53 animals was used to determine gene order. The number of animals observed with each haplotype is listed below the schematic of the chromosome. The C57BL/6J and SPRET/Ei alleles are depicted at each locus tested by closed or open boxes, respectively. All other gene orders resulted in multiple double-crossover events. The genetic distance (cM) and standard error were calculated as previously described (Buckwalter et al. 1991). The locations of the human genes are given in parentheses (Arbiser et al. 1988; Ginns et al. 1985; Nakai et al. 1987; Seigel et al. 1984).

Acknowledgments. We especially thank M. Meisler for providing DNA samples for the interspecific backcross, Nils Bergenheim and Pat Venta for probes and advice, our support from grants R29MH49463-01 (S.A. Camper), R29DK42730 (A.F. Seasholtz) and the University of Michigan Reproductive Science Center Molecular Biology Core (National Institutes of Health P30-HD18258).

\section{References}

Arbiser, J.L., Morton, C.C., Bruns, G.A.P., Majzoub, J.A. (1988). Human corticotropin releasing hormone gene is located on the long arm of chromosome 8. Cytogenet. Cell Genet. 47, 113-116.

Asa, S.L., Kovacs, K., Hammer, G.D., Lui, B., Roos, B.A., Low, M.J. (1992). Pituitary corticotroph hyperplasia in rats implanted with a medullary thyroid carcinoma cell line transfected with a corticotropin-releasing hormone complementary deoxyribonucleic acid expression vector. Endocrinology 131, 715-720.

Bain, P.A., Meisler, M.H., Taylor, B.A., Payne, A.H. (1993). The genes encoding gonadal and nongonadal forms of $3 \beta-$ hydroxysteroid dehydrogenase $/ \Delta^{5}-\Delta^{4}$ isomerase are closely linked on mouse chromosome 3. Genomics 16, 219-223.

Barrow, L.L., Simin, K., Mohlke, K., Nichols, W.C., Ginsburg, D., Meisler, M.H. (1993). Conserved linkage of neurotrophin 3 and von Willebrand factor on mouse chromosome 6. Mammalian Genome 4, 343-345.

Beechey, C., Tweedie, S., Spurr, N., Ball, S., Peters, J., Edwards, Y. (1990). Mapping of mouse carbonic anhydrase-3, Car-3: another locus in the homologous region of mouse chromosome 3 and human chromosome 8. Genomics 6, 692-696.

Brown, M.R., Fisher, L.A. (1985). Corticotropin-releasing factor: effects on the autonomic nervous system and visceral systems. Fed. Proc. 44, 243-248.

Buckwalter, M.S., Katz, R.W., Camper, S.A. (1991). Localization of the panhypopituitary dwarf mutation $(d f)$ on mouse chromosome 11 in an intersubspecific backcross. Genomics 10, 515-526.

Buckwalter, M.S., Lossie, A.C., Scarlett, L.M., Camper, S.A. (1992). Localization of the HSA 5q genes Gabra-1, Gabrg-2, Il-4, Il-5 and Irf-I on MMU 11. Mammalian Genome 3, 604-607.

Dietrich, W., Katz, H., Lincoln, S.E., Shin, H.-S., Friedman, J., Dracopoli, N., Lander, E.S. (1992). A genetic map of the mouse suitable for typing intraspecific crosses. Genetics 131, 396-423.

Eicher, E.M., Stern, R.H., Womack, J.E., Davisson, M.T., Roderick, T.H., Reynolds, S.C. (1976). Evolution of mammalian carbonic anhydrase loci by tandem duplication: close linkage of 
Car-1 and Car-2 to the centromere region of chromosome 3 of the mouse. Biochem. Genet. 14, 651-660.

Fehm, H.L., Voigt, K.H., Lang, R., Hetzel, W.D., Pfeiffer, E.F. (1976). Adrenal insufficiency is secondary to hypothalamic corticotropin releasing factor insufficiency with hyperpigmentation: a case report. Horm. Metab. Res. 8, 470-474.

Feinberg, A.P., Vogelstein, B. (1982). A technique for radiolabeling DNA restriction endonuclease fragments to high specific activity. Anal. Biochem. 132, 6-13.

Fiorentino, L., Austen, D., Pravtcheva, D., Ruddle, F.H., Brownell, E. (1989). Assignment of the interleukin-2 locus to mouse chromosome 3. Genomics 5, 651-653.

Ginns, E.I., Choudary, P.V., Tsuji, S., Martin, B., Stubblefield, B., Sawyer, J., Hozier, J., Barranger, J.A. (1985). Gene mapping and leader polypeptide sequence of the human glucocerebrosidase: implications for Gaucher's disease. Proc. Natl. Acad. Sci. USA 82, 7101-7105.

Gold, P., Chrousos, G.P. (1985). Clinical studies with corticotropin releasing factor: implications for the diagnosis and pathophysiology of depression, Cushing's disease, and adrenal insufficiency. Psychoneuroendocrinology 10, 401-419.

Hammer, G.D., Mueller, G., Lui, B., Petrides, J.S., Roos, B.A., Low, M.J. (1992). Ectopic corticotropin-releasing hormone produced by transfected cell line chronically activates the pituitaryadrenal axis in transkaryotic rats. Endocrinology 130, 1975-1985.

Irwin, M., Hauger, R., Brown, M. (1992). Central corticotropinreleasing hormone activates sympathetic nervous system and reduces immunological functions: increased responses of the aged rat. Endocrinology 131, 1047-1053.

Koob, G.F., Bloom, F.E. (1985). Corticotropin-releasing factor and behavior. Fed. Proc. 44, 259-263.

Krahn, D.D., Gosnell, B.A., Grace, M., Levine, A.S. (1986). Corticotropin releasing factor antagonist partially reverses CRF- and stress-induced effects on feeding. Brain Res. Bull. 17, 285-289.

Krahn, D.D., Gosnell, B.A., Majchrzak, M.J. (1990). The anorexic effects of CRH and restraint stress decrease with repeated exposures. Biol. Psychiatry 27, 1094-1102.

Levine, A.S., Rogers, B., Kneip, J., Grace, M., Morley, T.E. (1983). Effect of centrally administered corticotropin releasing factor (CRF) on multiple feeding paradigms. Neuropharmacology 22, 337-339.

Meisler, M.H., Seldin, M.F. (1991). Mouse Chromosome 3. Mammalian Genome 1 (Suppl), S42-S50.

Nadeau, J.H., Davisson, M.T., Doolittle, D.P., Grant, P., Hillyard, A.L., Kosowsky, M.R., Roderick, T.H. (1992). Comparative map for mice and humans. Mammalian Genome 3, 480-536.

Nakahara, M. (1983). Corticotropin-releasing factor tests in normal subjects and patients with hypothalamic-pituitary-adrenal disorders. J. Clin. Endocrinol. Metab. 57, 963-968.

Nakai, H., Byers, M.G., Venta, P.J., Tashian, R.E., Shows, T.B. (1987). The gene for human carbonic anhydrase II (CA2) is located at chromosome 8q22. Cytogenet. Cell Genet. 44, 234-235.

Nelson, D.H. (1989). Cushing's syndrome. Endocrinology 2, 1600 1675 .

Nemeroff, C.B., Widerlov, E., Bissette, G., Walleus, H., Karlsson, I., Eklund, K., Kilts, C.D., Loosen, P.T., Vale, W. (1984). Elevated concentrations of CSF corticotropin-releasing factor-like immunoreactivity in depressed patients. Science 226, 1342-1343.

Sambrook, J., Fritsch, E.F., Maniatis, T. (1989). Molecular Cloning: A Laboratory Manual. (Cold Spring Harbor, N.Y.: Cold Spring Harbor Laboratory Press).

Seasholtz, A., Bourbonais, F., Harnden, C., Camper, S. (1991). Nucleotide sequence and expression of the mouse corticotropinreleasing hormone gene. Mol. Cell. Neurosci. 2, 266-273.

Seigel, L.J., Harper, M., Wong-Staal, F., Gallo, R.C., Nash, W.G., O'Brien, S.J. (1984). Gene for T-cell growth factor: location on human $4 \mathrm{q}$ and feline chromosome B1. Science 223, 175-178.

Sirinathsinghji, D.J.S., Rees, L.H., Rivier, J., Vale, W. (1983). Corticotropin-releasing factor is a potent inhibitor of sexual receptivity in the female rat. Nature 305, 232-235.

Stenzel-Poore, M.P., Cameron, V.A., Vaughan, J., Sawchenko, P.E., Vale, W. (1992). Development of Cushing's syndrome in corticotropin releasing factor transgenic mice. Endocrinology 130, 3378-3386.

Sternberg, E.M., Scott Young III, W., Bernardini, R., Calogero, A.E., Chrousos, G.P., Gold, P.W., Wilder, R.L. (1989). A central nervous system defect in biosynthesis of corticotropin releasing hormone is associated with susceptibility to streptococcal cell wall-induced arthritis in Lewis rats. Proc. Natl. Acad. Sci. USA $86,4771-4775$.

Sutton, R.E., Koob, G.F., LeMoal, M., Rivier, J., Vale, W.W. (1982). Corticotropin-releasing factor produces behavioral activation in rats. Nature 297, 331-333.

Vale, W., Spiess, J., Rivier, C., Rivier, J. (1981). Characterization of a 41-residue ovine hypothalamic peptide that stimulates secretion of corticotropin and beta-endorphin. Science 213, 1394-1397.

Vale, W., Vaughan, J., Smith, M., Yamamoto, G., Rivier, J., Rivier, C. (1983). Effects of synthetic ovine corticotropin-releasing factor, glucocorticoids, catecholamines, neurohypophyseal peptides, and other substances on cultured corticotropic cells. Endocrinology 113, 1121-1131.

Venta, P.J., Montgomery, J.C., Hewett-Emmett, D., Wiebauer, K., Tashian, R.E. (1985). Structure and exon to protein domain relationships of the mouse carbonic anhydrase II gene. J. Biol. Chem. $260,12130-12135$. 